\title{
The role of explicit and implicit confidence in multi-stage decisions
}

\author{
Fatemeh Majdabadi ${ }^{1}$, Reza Ebrahimpour ${ }^{2}$
}

1. MS of Cognitive Science, Department of Cognitive Psychology, Institute for Cognitive Science Studies, Tehran, Iran

2. Professor of Artificial Intelligence, Department of Artificial Intelligence, Faculty of Computer Engineering, Shahid Rejaee Teacher

Training University, Tehran, Iran

Recieved: 22 Jan. 2020

Revised: 20 Sep. 2020

Accepted: 25 Sep. 2020

\section{Keywords}

Perceptual decision-making

Multi-stage decisions

Confidence

\section{Corresponding author}

Reza Ebrahimpour, Professor of Artificial Intelligence, Department of Artificial Intelligence, Faculty of Computer Engineering, Shahid Rejaee Teacher Training University, Tehran, Iran

Email: Rebrahimpour@srttu.edu

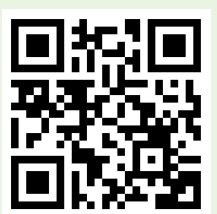

\section{Abstract}

Introduction: The present study aims to investigate the role of explicit confidence versus implicit in the context of studying how to set the strategy of multi-stage decisions. In this study, two-stage decision-making has been used as a suitable context to examine this difference. This issue is significant because the formation of confidence has been one of the most crucial questions posed. This study aims to provide a better view of confidence and its effect on the different elements of decision-making.

Methods: This research was an experimental study with a within-subject design. The experiments were done on a sample of 12 people (10 man, 22-36 years old), selected through convenience sampling. Each participant completed a total of 528 tests in four blocks of random dot motion. Participants had to make two consecutive perceptual decisions simultaneously with the answer. They announced their degree of certainty with a visual saccade. The testing and data analysis was done in MATLAB.

Results: The results of the Kruskal-Wallis test showed that reducing the motion strength in the first decision leads to increasing the response time of the second decision. Besides, a higher level of confidence in the first decision leads to an increase in the second decision's response time. The results of the Wilcoxon test indicated that the confidence of the first decision has a greater effect on the response time of the second decision in comparison to the effect of the accuracy of the first decision on the response time of the second decision. Conclusion: When the confidence level of each decision is consciously reported, simultaneously with their responses, it has the same effect on the strategy's setting as the lack of reporting uncertainty. Accordingly, it can be concluded that in the context of multi-stage perceptual decisions, explicit and implicit confidence act similarly.

Citation: Majdabadi F, Ebrahimpour R. The role of explicit and implicit confidence in multi-stage decisions. Advances in Cognitive Sciences. 2020;22(3):37-47. 


\title{
نقش قطعيت آكاهانه و ضمنى در بستر تصميمهاى جند مر حلهاى
}

\author{
فاطمه مجد آبادى'، رضا ابر اهيم يور \\ 1. كارشناسى ارشد علوم شناختى، كروه روان شناسى شناختى، موسسه آموزش عالى علوم شناختى داختى، تهران، ايران

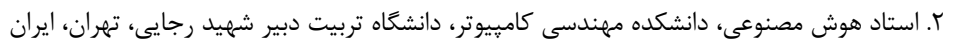

\begin{abstract}
בris
مقدمهه: هدف اين يزوهش به دنبال بررسى نقش قطعيت آكاهانه در مقابل قطعيت ضمنى در بستر مطالعه جگگونكى تنظيم استراترى تصميمهاى حند مرحلهاى است. در اين مطالعه، از تصميمى براى بررسى اين تفاوت استفاده شده است. اين موضوع از آنجا حائز اهميت است كه در مطالعات سالهاى اخير در حوزه تصميم گيرى، مساله شكلكيرى قطعيت از جمله سوالات مهمم بوده است. اين مطالعه مىتواند تصوير كاملترى از بازنمايى قطعيت و اثر آن بر مولفههاى تصميم را نشان دهد. دوش كار: اين يروهش از نوع آزمايشى با طح درون آزمودنى بود. در اين مطالعه از دادهاى آزمايش روان_فيزيك نقاط متحرك تصادفى rا شركت كننده كه به روش نمونه گيرى در دسترس انتخاب شده بودند، استفاده شد. هر شركت كننده

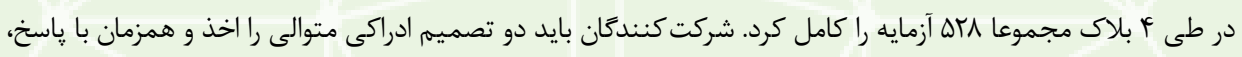
ميزان قطعيت خود را با ساكاد جشمى اعلام مى كردند. يافته ها: نتايج نشان داد كاهش قدرت محرى در تصميم اول به طرز معنادارى منجر به افزايش زمان پاسخ تصميم دوم مىشود. همجنين گزارش قطعيت بالاتر در تصميم اول به افزايش زمان پاسخ تصميم دوم منتهى مىشود. از طرفى نتايج نشان داد قطعيت تصميم اول بر زمان پاسخ تصميم دوم به طرز معنادارى اثر بيشترى نسبت به تاثير صحت تصميم اول بر زمان پِاسخ تصميم دوم دارد. نتيجه كَيرى: هنكَامى كه قطعيت در مورد هر تصميهم به صورت همزمان با پاسخ و آحاهانه كزارش مىشود همان اثرى را بر تنظيم استراترى مى خذارد كه در عدم كزارش قطعيت ديده مىشد. بر همين اساس مىتوان عنوان كرد كه در بستر تصميمات جند مرحلهاى ادراكى، قطعيت آكاهانه و ضمنى مشابه با يكديخر عمل مى كنند.
\end{abstract}

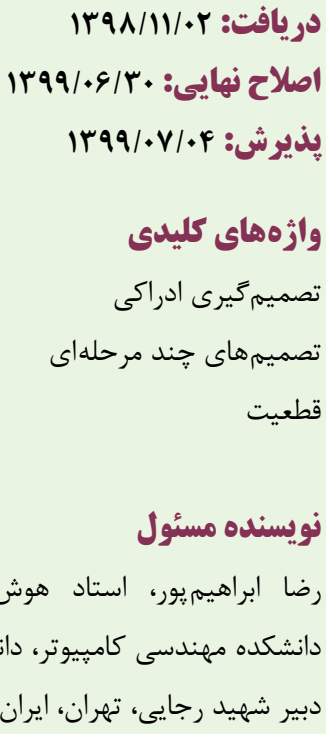

ايميل: : Rebrahimpour@srttu.edu

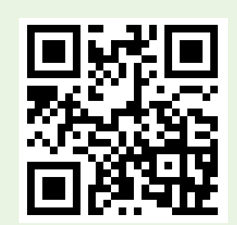

dol doi.org/10.30699/icss.22.3.37

مقدمبه

تحقيقات بعدى نشان داد، در برخى شرايط رفتار تصميمىيرنده بهينه

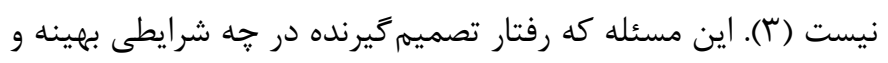
در جه شرايطى غير بهينه است هنوز محل يثوهش است (Y). تحقيقات متعددى نشان داده كه رفتار شركت كننده در آزمونهاى روان_فيزيكِ حسى_حركتى نزديك به عملكرد بهينه است (ه). به جنين تصميماتى
تصميمگيرى يكى از بالاترين سطوح فعاليتهاى شناختى مغز است

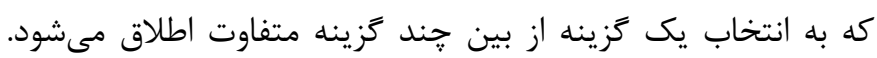
اولين نظريههاى كلاسيك تصميمگيرى توسط اقتصاددانها مطرح شد كه در آنها با توجه به الكوهاى رياضى سعى در تبيين رفتار انسانها

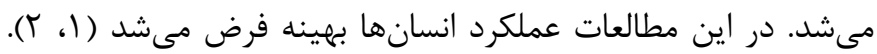


نقاط متحرك به شركت كننده نشان داده مىشود. اين نقاط يا به طرف

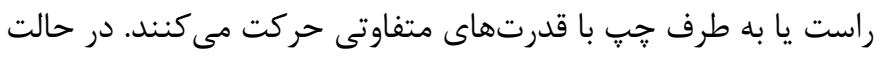

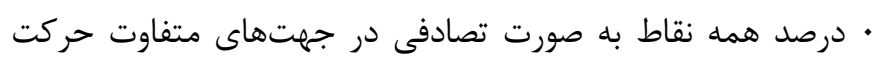

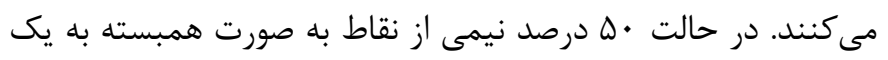

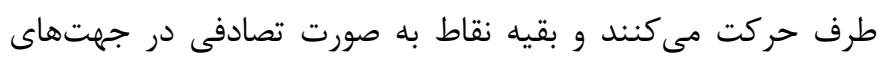

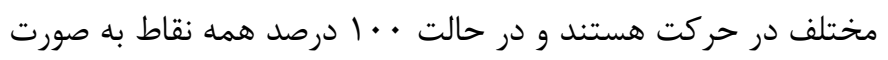

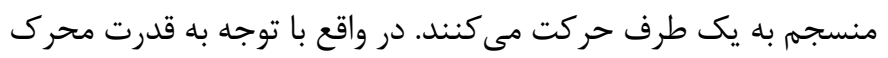

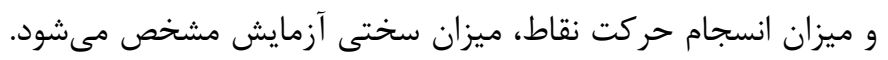
در آزمايشهايى كه از RDM استفاده مى كنند اين مجموعه نقاط به إنهان شركت كننده نشان داده شده و از شركت كننده خواسته مى شود جهت حركت نقاط را تشخيص دهد. هرجه ميزان انسجام حركت نقاط بيشتر

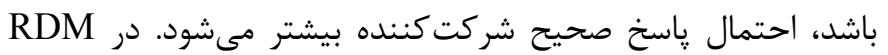

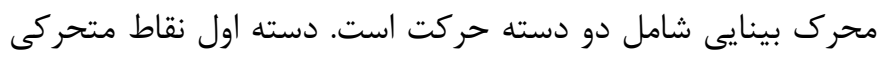

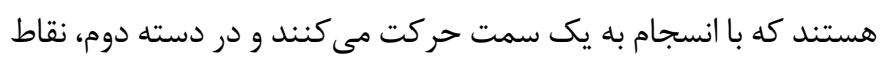

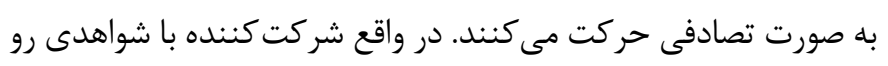

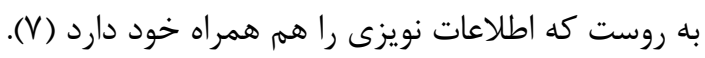
در زندگى روزمره رسيدن به يك هدف غالبا حاصل سلسلهاى از تصميم گيرىهاى يى در يى است كه بر روى يكديكر تاثير مى كذارند. مطالعه بر روى تصميمخيرىهاى متوالى نسبت به تصميم گيرىهاى

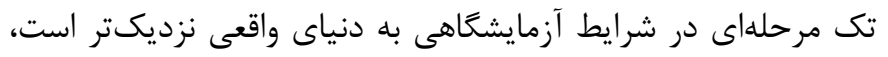
همين امر سبب اهميت اين نوع مطالعات مىشود. اين كه كدام مولفهها

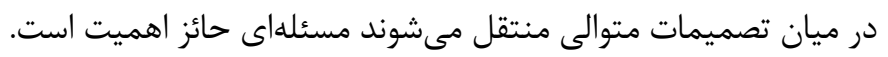

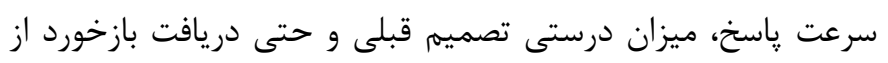

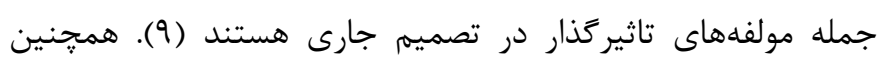

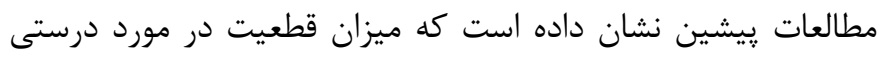

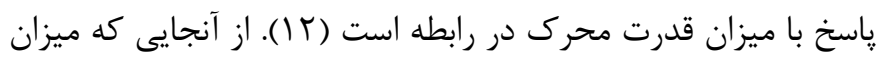

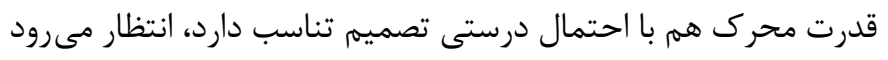

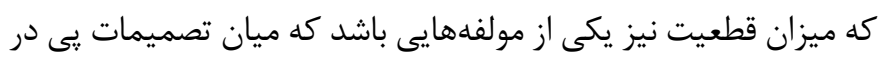

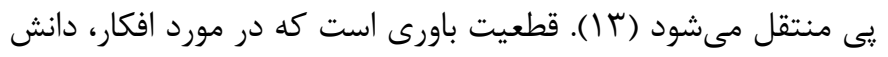

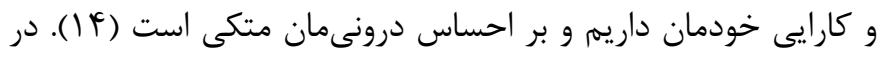

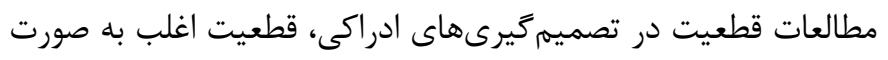

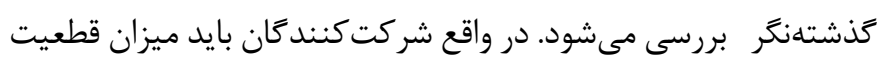

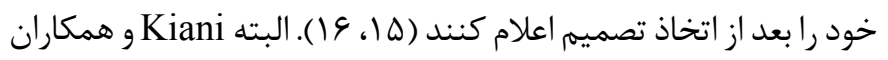

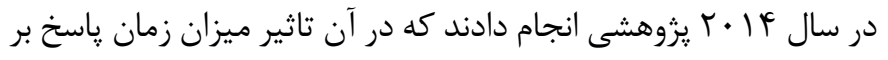

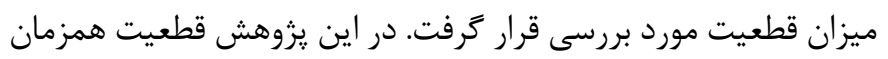

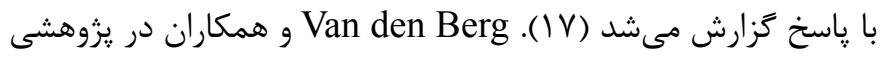
عملكرد شركت كنندكان در سلسلهاى از تصميمات كه در آن صحت
كه مستقيما توسط سيستم حسى_حركتى اتخاذ مىشود، تصميمات

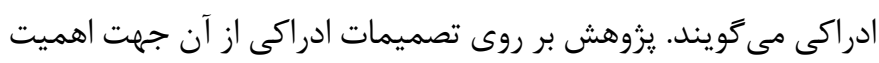

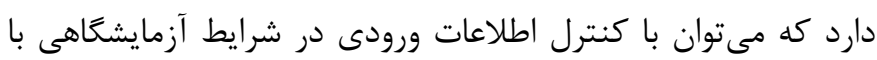
دقت بيشترى در مورد نحوه تاثير اطلاعات ورودى بر شكل خيرى تصميم

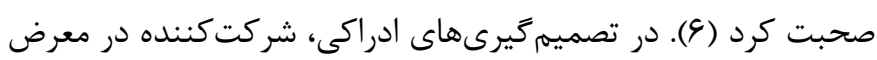

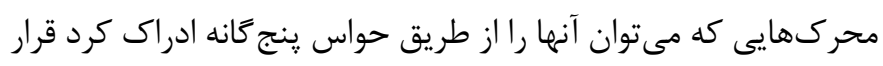

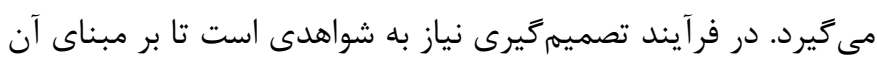

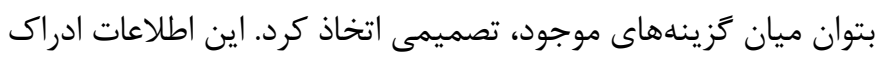
شده همان شواهدى هستند كه به نفع كزينهها وزندهى مي شيوند. اطلاعات به صورت ييوسته در زمان، تا جايى كه به نفع يكى از تز ينهانها

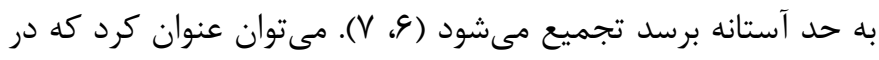

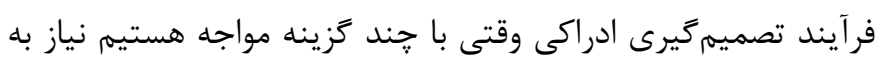

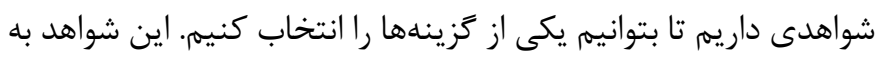
وسيله سيسته حسى دريافت شده و توسط فعاليت كروهى از نورونها

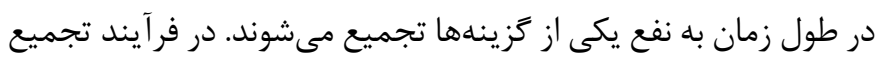

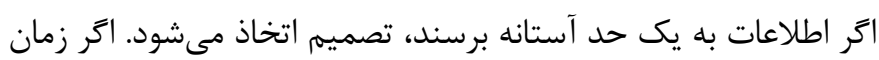

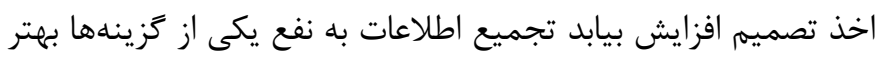
انجام مىشود و در اين حالت امكان خطا كاهش مى يابد. در مقابل اكر

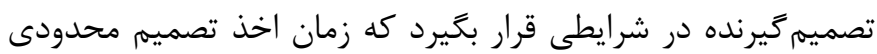

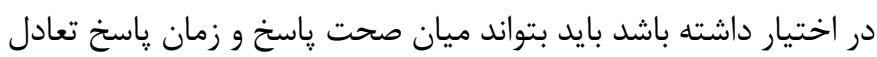
برقرار كرده و به صورت بهينه عمل كند (1-19).

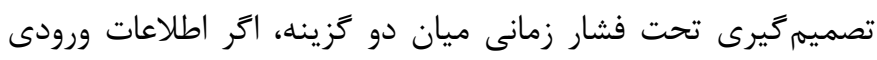

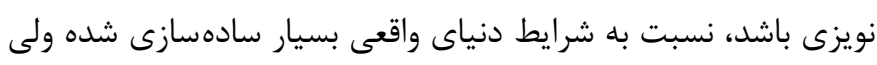

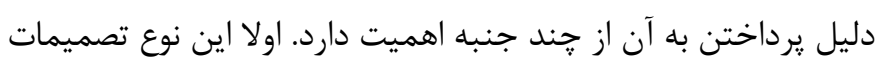
بازنماى شرايط مختلفى است كه حيوانات در آن قرار مى دئيرند. مثلا در مواجهه با يك محرى جديد به سمت آن بروند يا از آن دورى كنند.

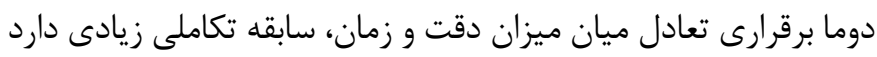

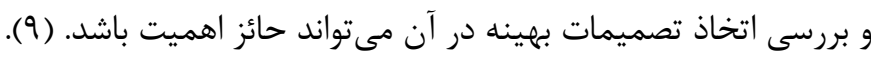

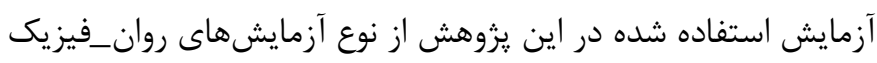

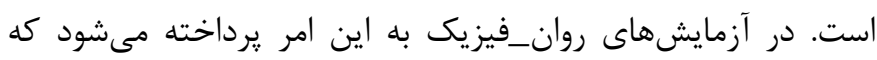

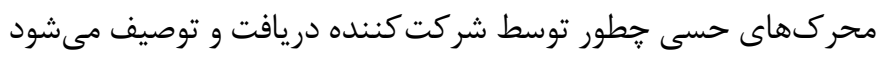

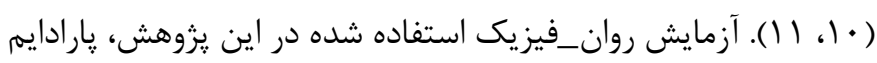

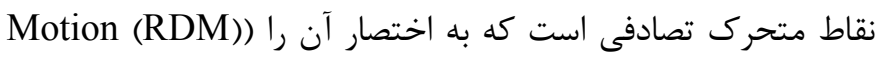
(Random Dots تصميم گيرى ادراكى طراحى شده و آزمايشهاى متعددى با استفاده از

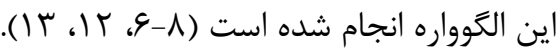

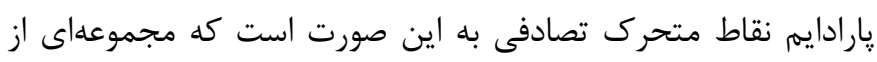


ردياب جشمى ثابت Eye link 1000 SR Research براى دريافت ياسخ و ززارش قطعيت استفاده شده است. محرك بينايى: آزمايش روان_فيزيك استفاده شده در اين يزوهش، آزمايش نقاط متحرك تصادفى است. آزمايشهاى متعددى با استفاده

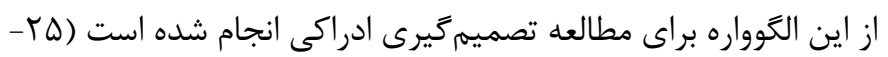

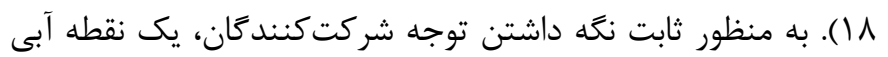
رنح به قطر كF/ • درجه بينايى به نمايش Fذاشته مىشد. اندازه نقاط

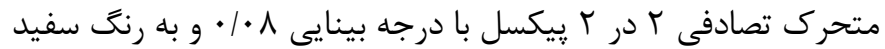

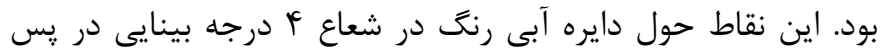

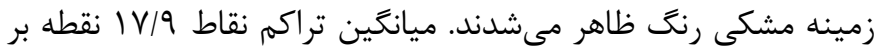
درجه بينايى بر واحد مربع در هر ثانيه و سرعت حركت نقاط ل V/ درجه بينايى بر ثانيه بود. هر محرك از مجموعههاى مستقل نقاط متحرى تشكيل شده بود كه به صورت فريمهاى ويدئويى يى در يى بر روى برى

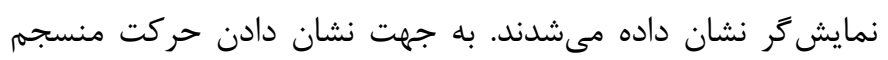

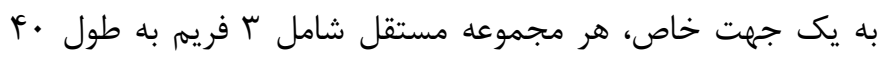
ميلىثانيه به يك جهت خاص حركت مى كرد. در اين آزمايش، جهتها در تصميم اول به طرف جֶٍ و راست و در تصميم دوم به طرف بالاو

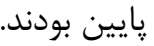
بازخورد: شركتكنندكان يس از اعلام ياسخ خود، بازخوردى شنيدارى

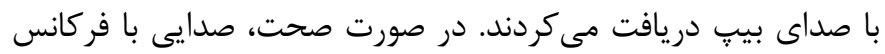
• • هرتز و در صورت عدم صحت صدايى با فركانس ب...1 هرتز

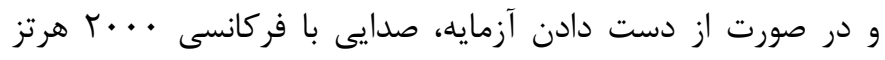

مىشنيدند. طرح آزمايش: اين يزوهش از نوع مطالعات آزمايشى با طرح

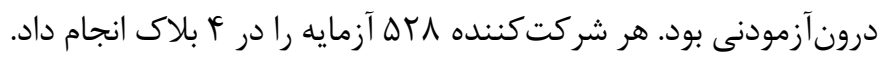
ميزان همسبتكى حركت نقاط متحرك در 9 سطح در تصميم اول و دوم به عنوان متغير مستقل و زمان ياسخ، صحت پاسخ و ميزان قطعيت هر تصميم به عنوان متغير وابسته در نظر كرفته شد.

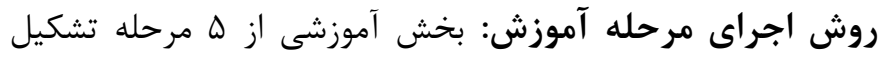

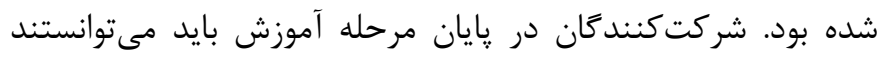

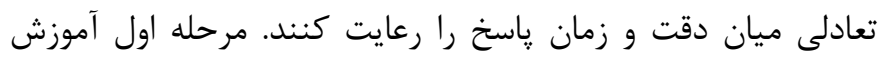

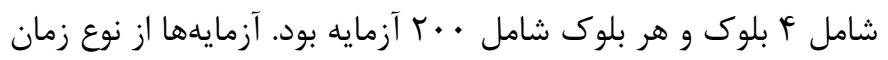

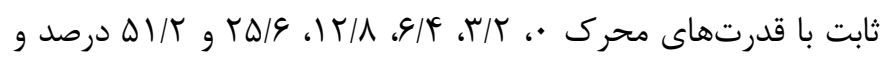
در زمانهاى متفاوت و به صورت تصادفى بودند. در حالت زمان ثابت ابتدا محرك بينايى با زمان مشخصى به شركت كنندكان نشان داده مىشود. يس از قطع شدن محرك، از شركت كنندكان خواسته مىشود

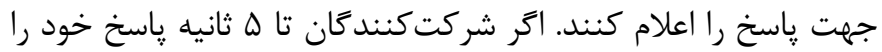

همه تصميمات منجر به دريافت ياداش مىشد را مورد مطالعه قرار دادند. Van den Berg نشان داد كه قطعيت تعادل ميان دقت و سرعت ياسخ تصميم دوم را تعيين مى كند. آنها با تخمين قطعيت تصميم اول، اين قطعيت را به عنوان مولفهاى براى تعيين استراتزى معرفى

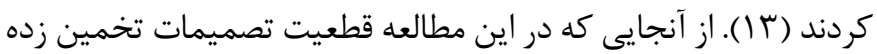
مىشد اين سوال مطرح است كه با كزارش قطعيت به صورت آكاهانه آيا همجنان قطعيت عامل تنظيم استراتزى است؟ اين موضوع از آنجا حائز اهميت است كه اولا نشان مىدهد كه در بستر تصمميات ادراكى جند مرحلهاى، نقش كليدى قطعيت در انتقال اطلاعات ميان دو تصميم، در شرايط كزارش آكاهانه قطعيت با شرايط محاسبه ضمنى قطعيت يكسان است. همين يافته مىتواند اعتبار مطالعات تصميمات ادراكى كه

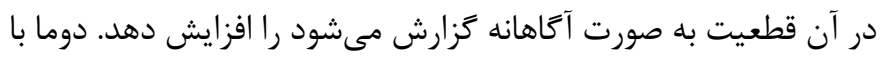
سنجش قطعيت به صورت آكاهانه، اثر قطعيت در انتقال اطلاعات ميان دو تصميم ادراكى با وضوح بيشترى قابل مشاهده است و مى توان تاثير

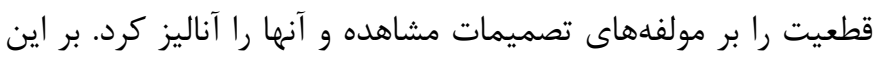
اساس هدف اين يزوهش بررسى نقش تنظيم كنندگى استراتزى توسط قطعيت آكاهانه در بستر تصميمات جند مرحلهاى بود. بورسي

\section{روش كار}

دادههاى به دست آمده در اين يزوهش از جا نفر (•آ آقا) به روش نمونه گيرى تصادفى در دسترس جمعآورى شده است. محدوده سنى شركت كنند كلاسهاى هوش مصنوعى دانشكاه شهيد رجايى به آزمايش راه راه بِ بيدا

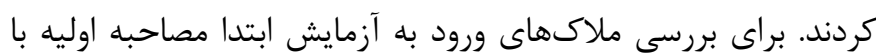
داوطلبان در محل آزمايشخاه صورت كرفت. داشتن ضعف بينايى، سابقه جراحى جشه، سابقه سايكوز، سابقه ADHD و سوءمصرف مواد مخدر به عنوان ملاكهاى خروج از آزمايش تعيين شد. در اين مرحله ب داوطلب از آزمايش حذف شدند و I I داوطلب باقى مانده همكى توانستند مرحله آموزش را يشتسر بحذارند و به آزمايش راه يابند. جهت رعايت ملاحظات

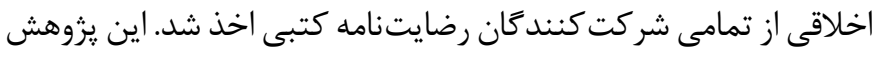
با كد IR.IUMS.REC13981002 به تصويب كميته اخلاقى معاونت يزوهش و فناورى دانشعاه علوم يزشكى ايران رسيده است.

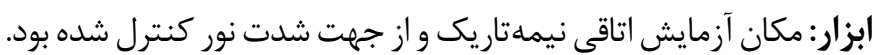

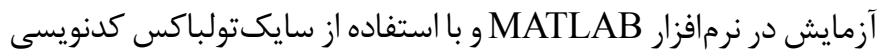

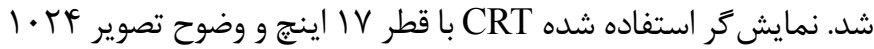

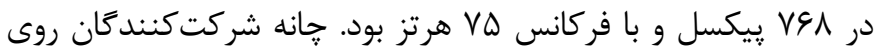
جينرست و با فاصله له سانتىمتر از نمايش گر قرار مى خرفت. از دستخاه 
به صورت تصادفى با يكى از قدرتهاى •، ז/K، \&/

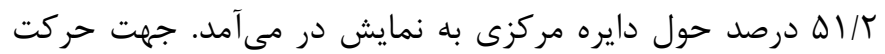

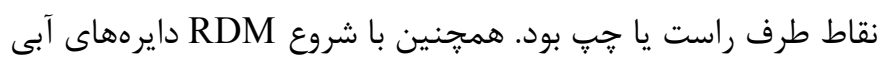
دو طرف نايديد و به جاى آنها دو مستطيل رنغى عمودى با طول و عرض ه/ • درجه بينايى با طيف رنكى قرمز تا سبز قرار مى گرفت. رنگ قرمز نشاندهنده • درصد و رنغ سبز نشاندهنده . ․ ميزان قطعيت بود. از شركت كنندكان خواسته شده بود هم زمان با اعلام ياسخ خود در مورد جهت حركت RDM، ميزان قطعيت خود در مورد درستى ياسخ اعلام شده را ززارش دهند. وقتى جشم درجه بينايى از دايره مركزى فاصله مى ثبت و بلافاصله RDM قطع مىشد. همجنين پس از اعلام جهت ياسخ و ميزان قطعيت، مستطيلهاى رنگى نايديد مىشدند. جهتى كه شركت كنند منزله نقطه مركزى براى تصميم دوم تلقى مىشد و دايره آبى رنى در همان جهت دوباره يديدار مى گرديد. در تصميم دوم نيز نگاه شركت كنندكان ابتدا . . ب ميلى ثانيه بر روى نقطه آبى رنگ مركزى جديد ثابت و يس از طى شدن يك زمان تصادفى، RDM تصميم دوم حول نقطه مركزى جديد يديدار مى شد. همزمان با شروع RDM دو مستطيل رنكى با مشخصاتى مشابه تصميهم اول در بالا و پايين دايره آبى مركزى جديد ظاهر مىشد با اين تفاوت كه مستطيلها

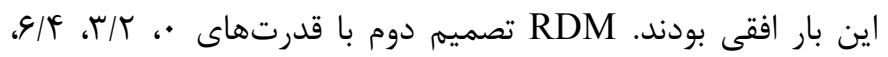

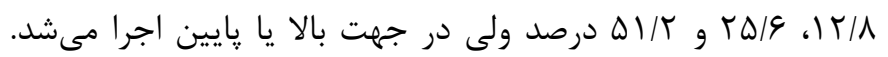

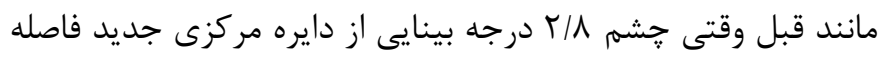

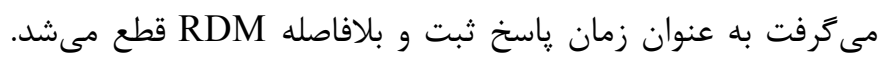
صفحه نمايش گر بعد از تصميم دوم به حالت اوليه خود در مى آمد و بسته به اين كه شركت كننده در طى اين دو تصميم به كدام مربع

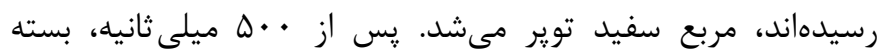
به اين كه كدام مربع انتخاب شده بود مستطيل رنكى ديخرى با فاصله ب درجه بينايى بالاتر از هدف انتهايى در نمايش گر نشان داده مىشد. در اينجا شركتكنندكان بايد ميزان قطعيت خود در مورد درستى هر دو تصميم را اعلام مى كردند. يس از اعلام ميزان قطعيت، بازخورد شنيدارى در مورد درستى هر دو تصميهم به شركت كنند داده مىشد. به اين صورت كه اخر بازخورد مثبت دريافت مى كردند نشاندهنده اين بود كه هر دو تصميم را درست تشخيص دادهاند. در آزمايههاى تك تصميم اول، همه جيز مانند دو تصميمه بود با اين تفاوت كه بعد از اتخاذ تصميم اول، تصميم دومى وجود نداشت و بازخورد مربوط به درستى همان تصميم بود.
اعلام نمى كردند آن تصميم از دست رفته تلقى مىشد. يس از يايان هر تصميم، به شر كت كنندكان در مورد صحت تصميه بازخورد صوتى داده مىشد. براى محركهاى • درصد بازخورد به صورت تصادفى با احتمال

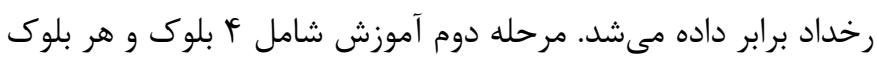

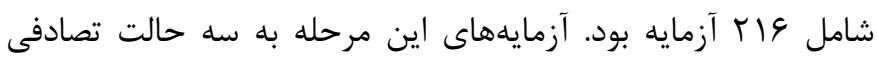
ارائه مىشدند. حالت اول مشابه مرحله اول آموزش بودند، با اين تفاوت كه RDM به صورت زمان آزاد ارائه مىشد. در حالت زمان آزاد محرك بينايى به شركت كنند مى توانند محرك بينايى را تا زمان لحظه اتخاذ تصميم مشاهده كنند. حالت دوم و سوم نيز مشابه حالت اول بودند با اين تفاوت كه جهت

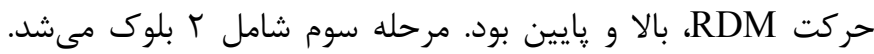
طراحى اين مرحله مانند مرحله اصلى آزمايش ولى شامل 99 آزمايه دو تصميمه بود با اين تفاوت كه در هيج مرحلهاى قطعيت ززارش نمىشد و بازخورد مثبت تنها در صورت درست بودن هر دو تصميمم ارائه مىشد. مرحله جههارم شامل r بلوك مشابه مرحله اصلى ولى با له آزمايه دو تصميمه بود. شركتكنندكان بايد در انتهاى آزمايه ميزان قطعيت خود در مورد درستى هر دو تصميم را اعلام مىكردند سيس مانند قبل بازخورد دريافت مى كردند. مرحله ينجمه آزمايش كاملا مشابه آزمايش اصلى بود با اين تفاوت كه شامل ا بلوك با إل آ آزمايه دو تصميمه مىشد. اين مرحله براى آشنايى شركت كنندگان با آزمايش اصلى طراحى شده بود.

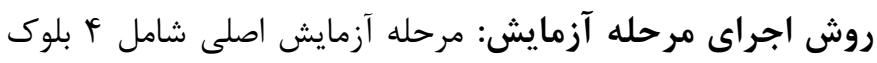

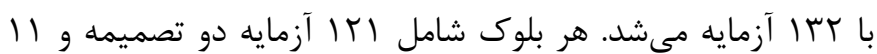
آزمايه تك تصميم اول بود. طراحى آزمايش در شكل ا به صورت شماتيك نشان داده شده است. همه آزمايهها از نوع زمان آزاد بودند. در آزمايههاى دو تصميمه ابتدا يك دايره آبى رنت به قطر ب؟F/• درجه بينايى در مركز تصوير و دو دايره آبى رنگ ديكر با قطر بأ/• درجه بينايى هر كدام با فاصله 9 درجه بينايى در سمت راست و جٍ دايره آبى رنگ مركزى قرار داده شده بود. جهار مربع توخالى سفيد رنت هر

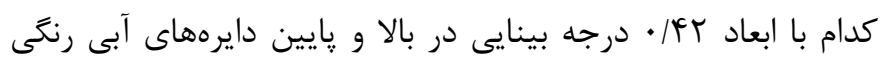
جֶٍ و راست نمايش داده مىشد. از شركت كنندگان خواسته شده بود نعاه خود را بر روى دايره آبى رنت مركزى ثابت نخه دارند. دايرهاى به رابه شعاع T/K درجه بينايى حول دايره آبى رنگ مركزى تعريف شده بود. ثابت نَّه داشتن جشم شركت كنندگًان با دستخاه ردياب جشمى كنترل مىشد.

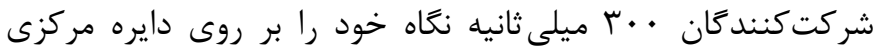
ثابت نحه مىداشتند. پس از سيرى شدن زمانى تصادفى يك RDM 


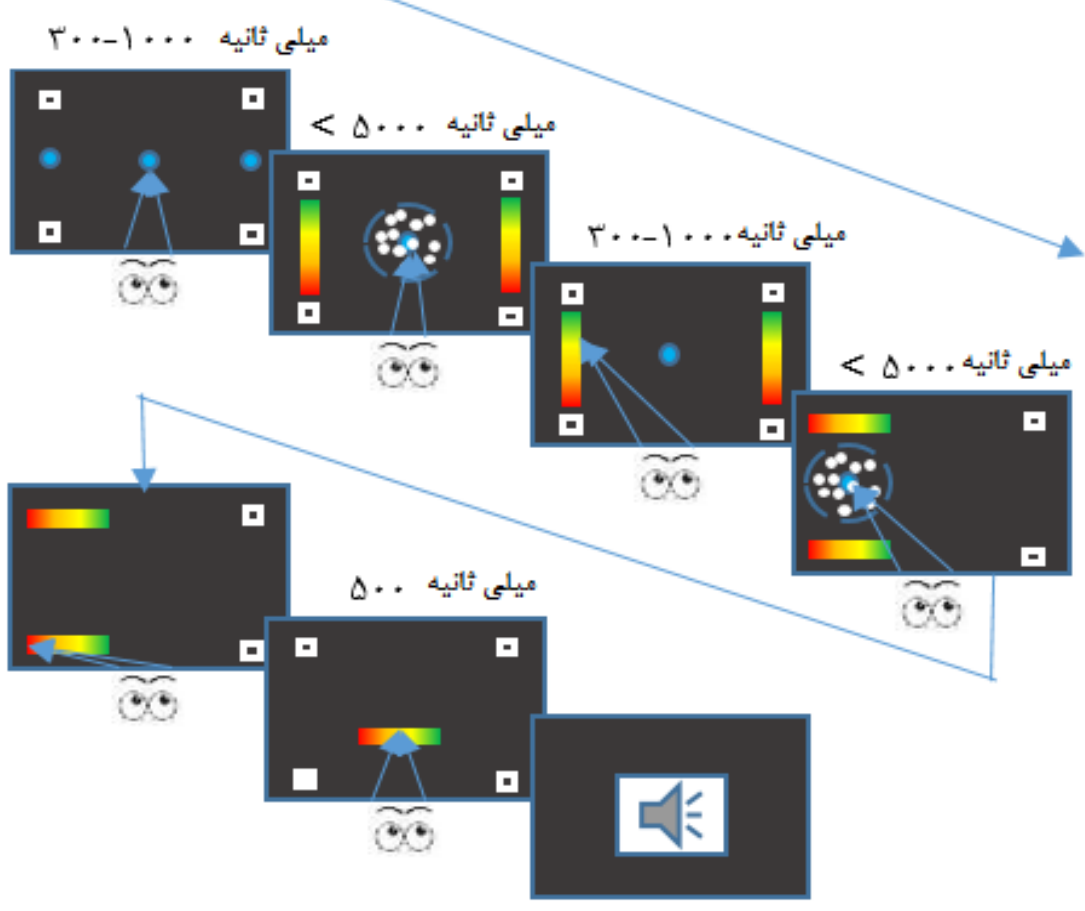

$\widetilde{\infty}$

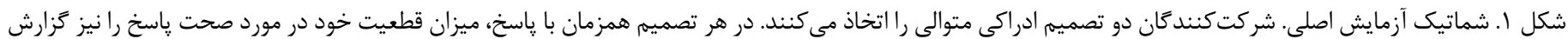

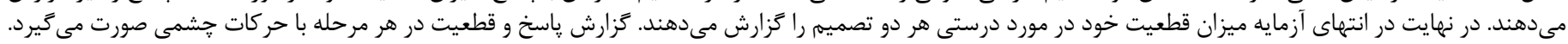

(شكل r- قسمت ج و ه) استفاده شده است. اندازه نمونههاى هر

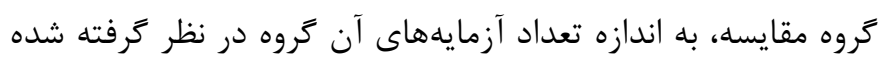

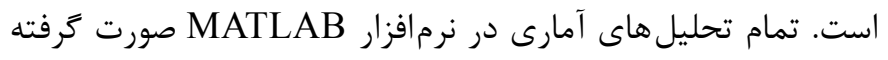

است.
نحوه تجزيه و تحليل دادهها: با توجه به اين كه دادهها در شرايط

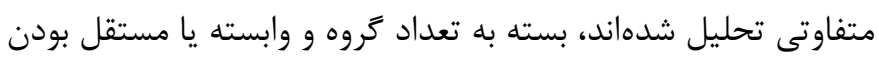

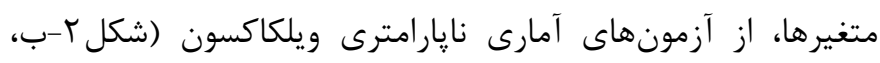

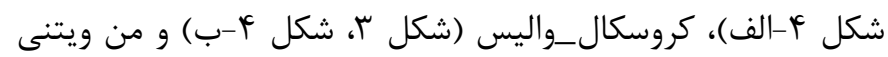
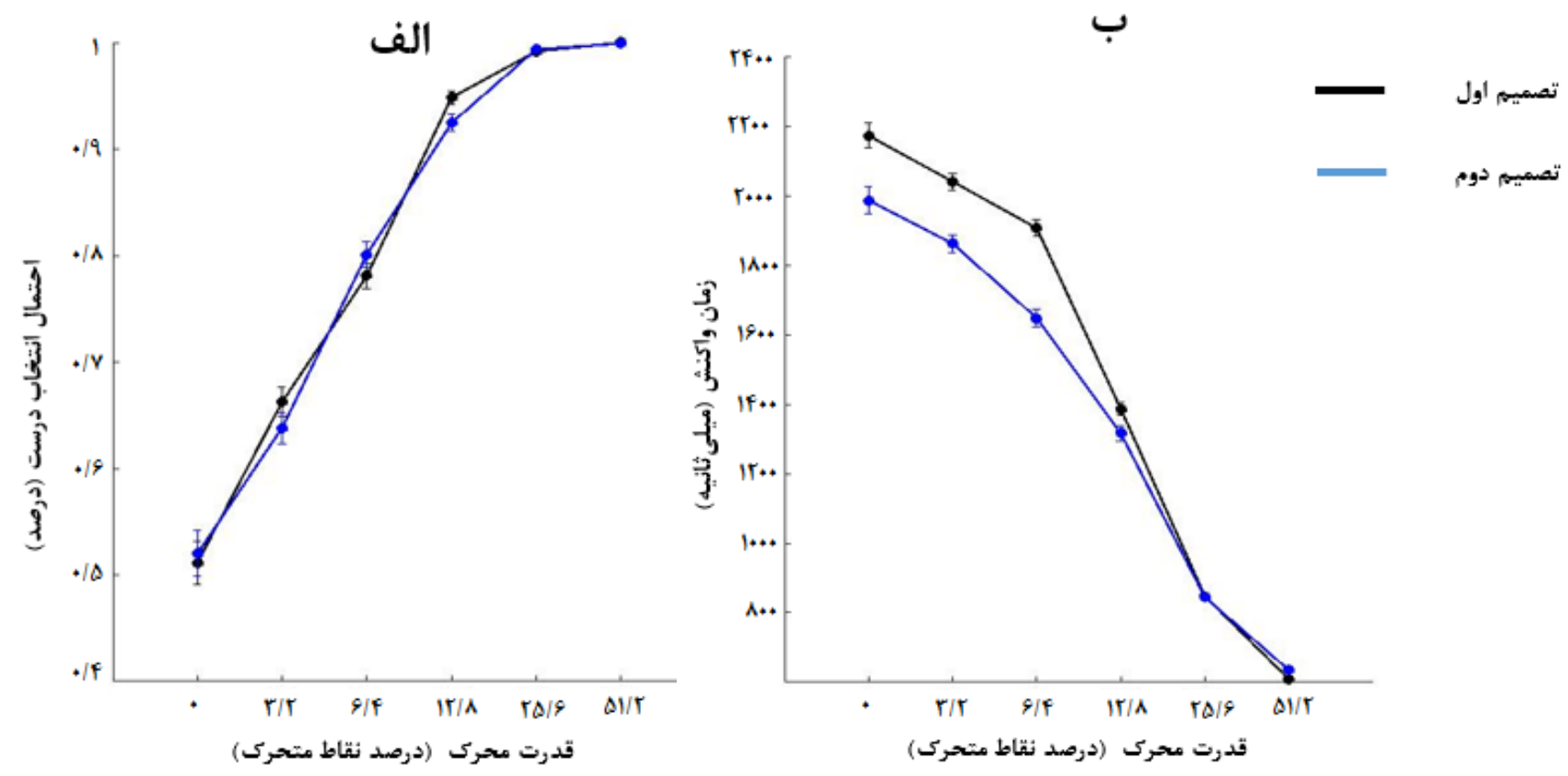

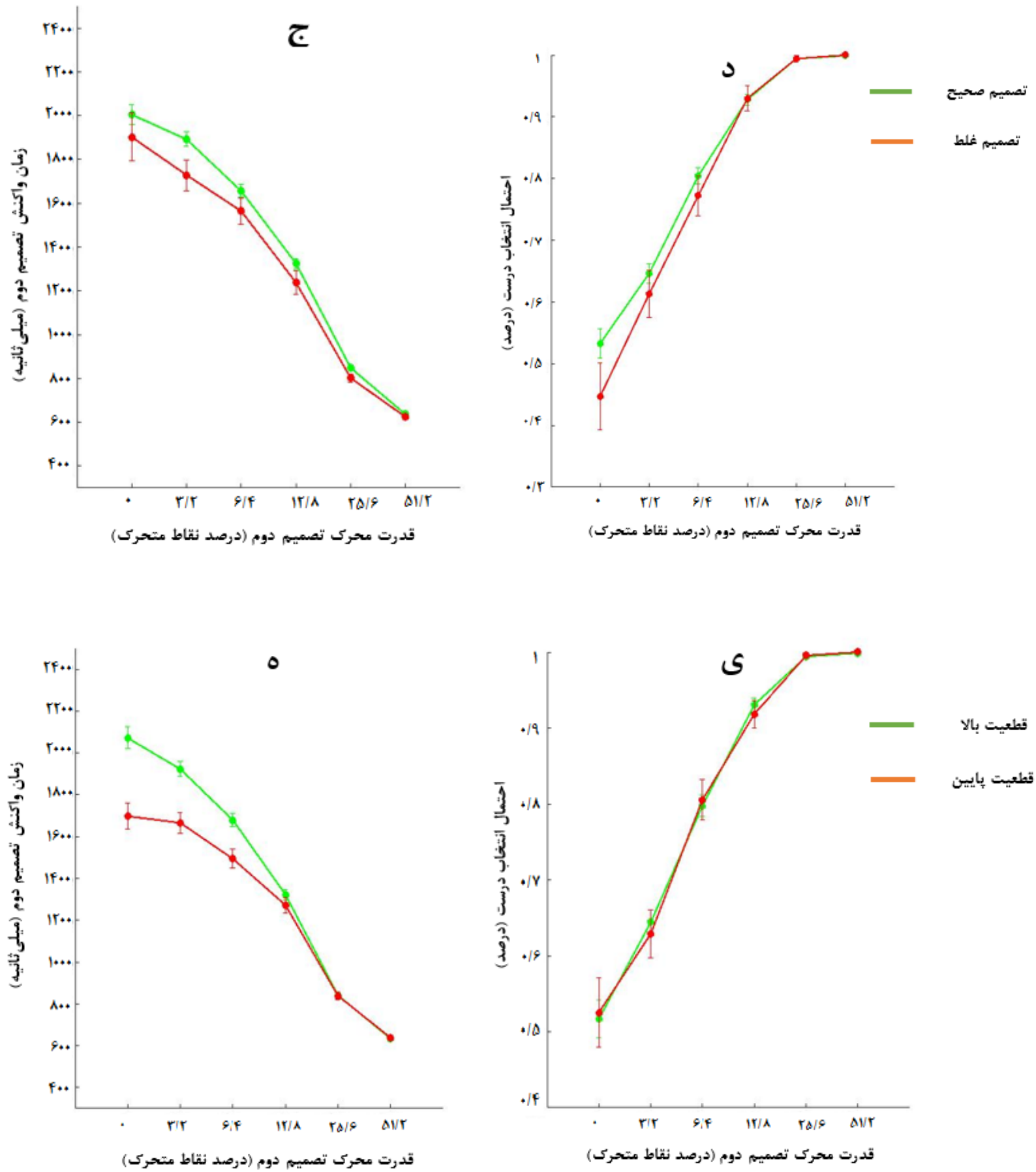

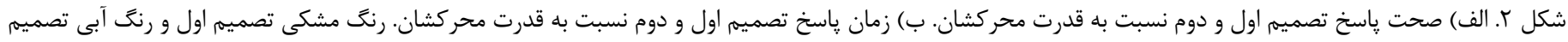

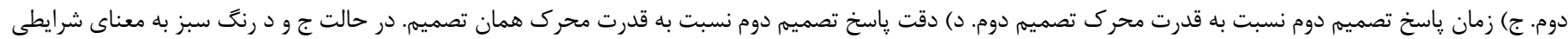

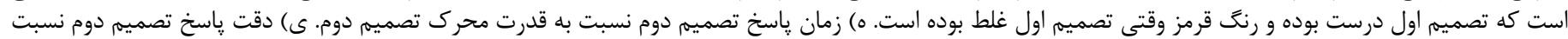

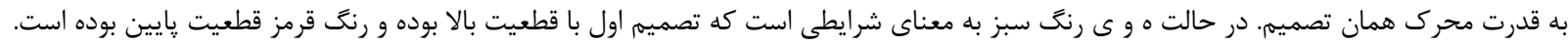

يافتهه ها

به تصميم دوم صرف كردهاند و اين تفاوت با استفاده از آزمون آمارى براى مطالعه رفتار بهينه شركت كنندكان در اتخاذ تصميمات متوالى، در

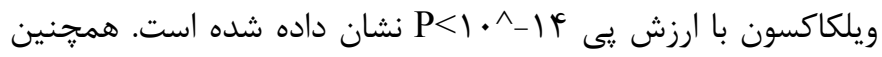
قدم اول به تحليل دقت و زمان ياسخ آنها نسبت به قدرتهاى محرى شركت كنندكان تصميم اول را با دقت بيشترى نسبت به تصميم دوم

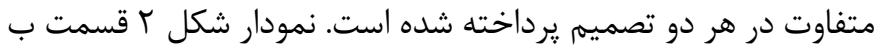
ياسخ دادهاند. گرجه اين تفاوت معنادار نبود (شكل r قسمت الف). يكى نشان مىدهد شركتكنندكان در تصميم اول زمان بيشترى را نسبت 
اكر ميزان قطعيت پاسخ تصميم اول را به دو گروه قطعيت بالاو قطعيت

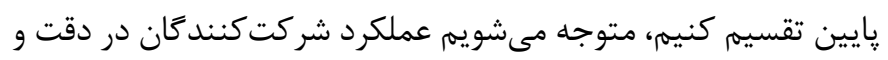

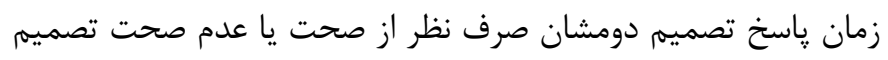

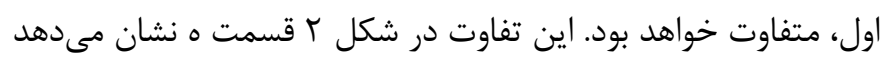

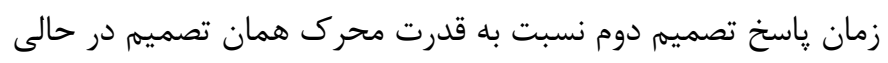

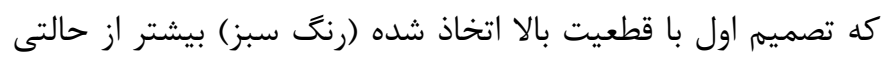

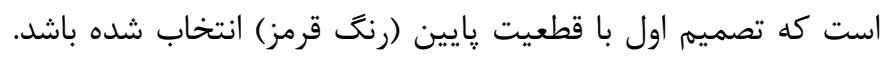

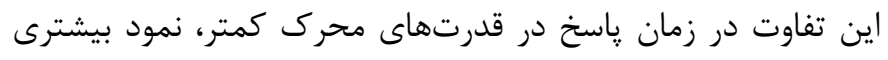

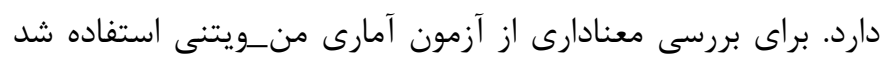

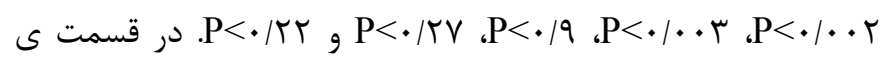
اين شكل احتمال درستى ياسخ تصميم دوم در شرايطى كه تصميم

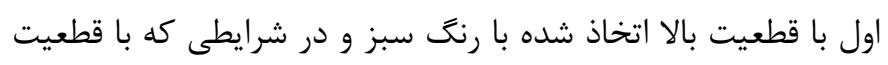

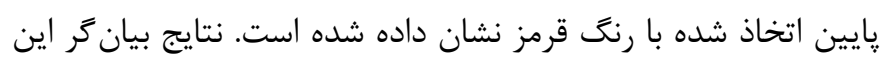

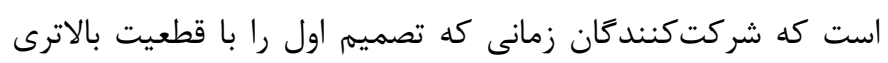

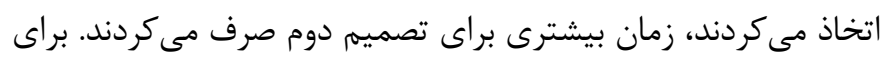

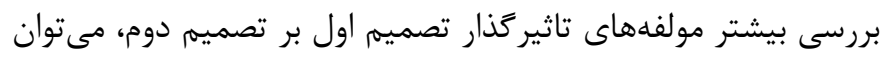

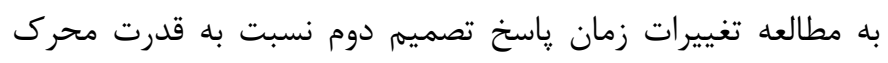

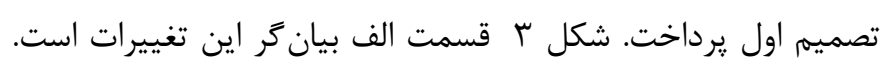

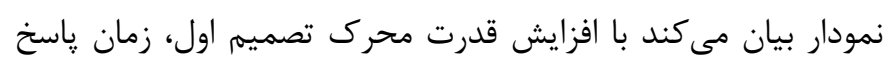
تصميم دوم نيز افزايش مى يابد.
ديخر از مولفههاى قابل بررسى ميزان تاثير كذارى صحت تصميم اول بر

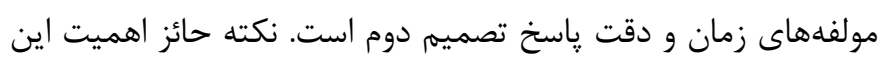
است كه در اين يزوهش، شركت كنند

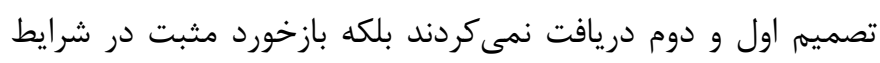

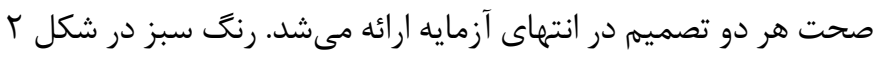

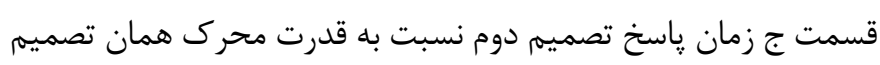

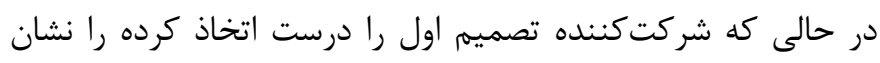

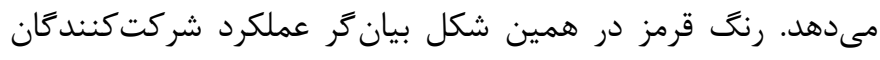

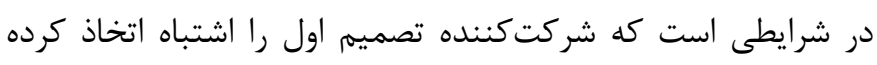

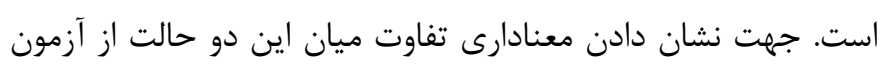

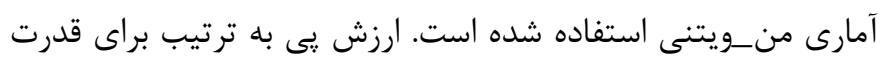

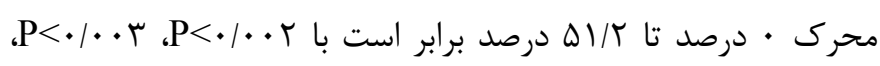

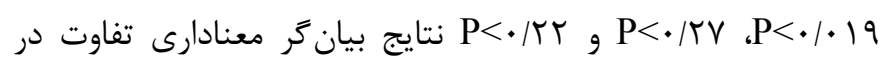
قدرتهاى محرى كمتر است. در قسمت د شكل r ب دادههاى رفتارى

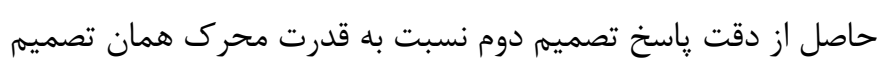

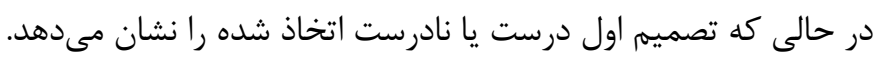

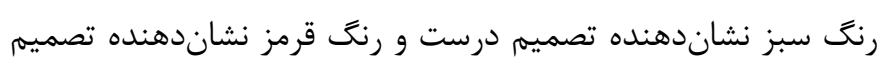

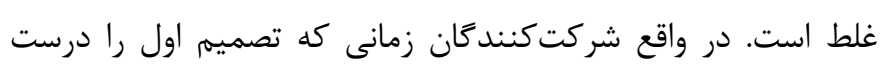

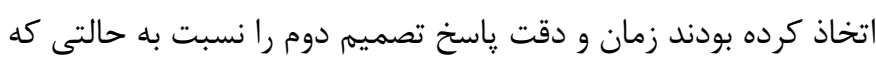

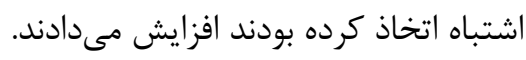
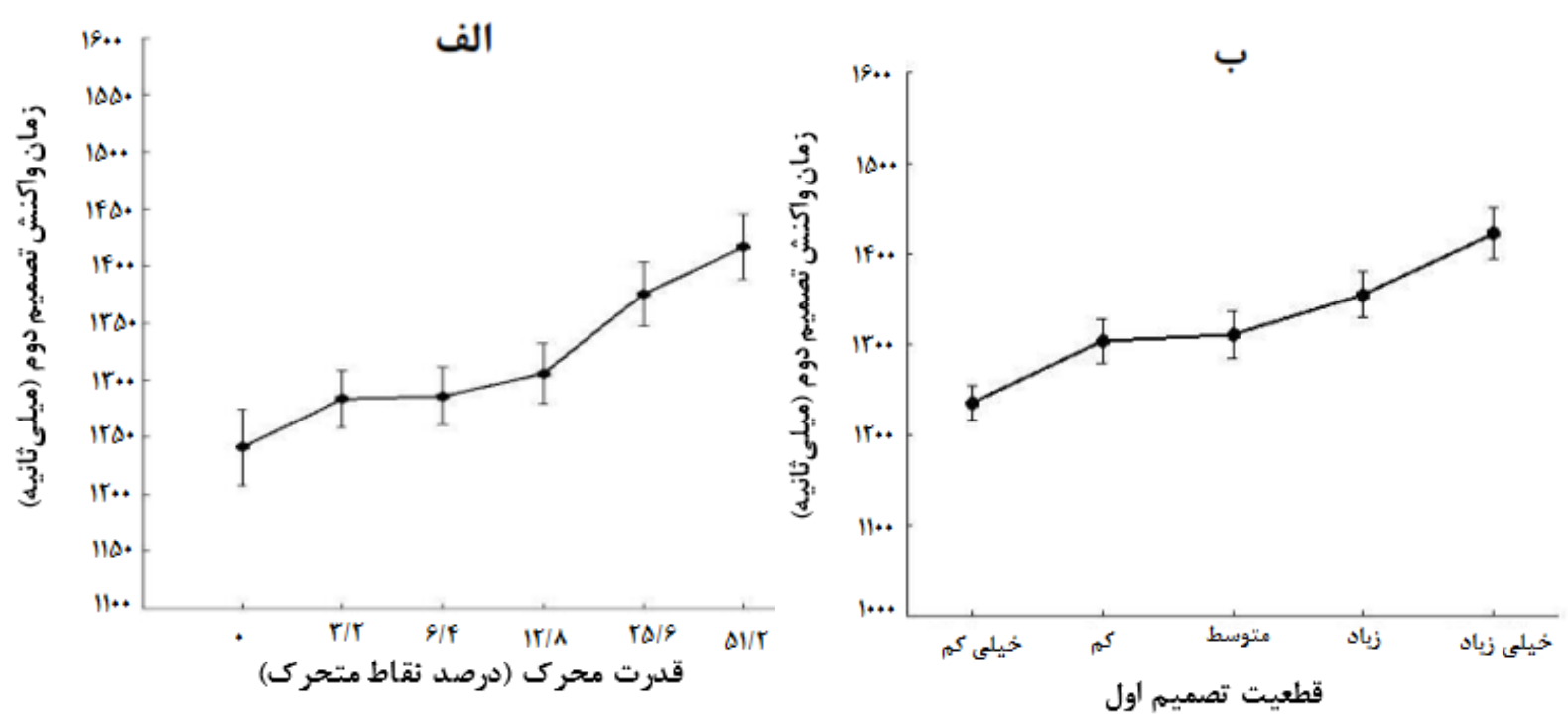

شكل ऍ. الف) زمان پِاسخ تصميم دوم نسبت به قدرت محرك تصميم اول، ب) زمان پِاسخ تصميم دوم نسبت به ميزان قطعيت تصميم اول

نشاندهنده معنادارى اين تغييرات است (9 • • P> (9). قسمت ب شكل

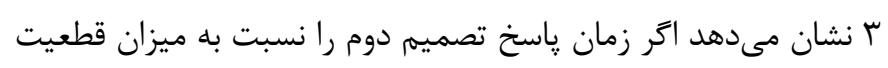

در واقع هرجه تصميم اول سادهتر باشد، شركت كنندكان زمان بيشترى

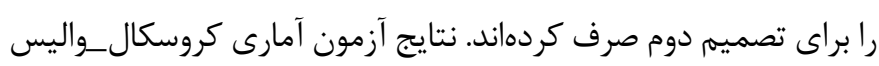


قدرت محرك در هر دو تصميم، ميزان قطعيت در مورد صحت تصميم افزايش مىيابد. به عبارتى ديخر هرجه تصميمى اتخاذ شده سادهتر باشد، ميزان قطعيت شركت كنند نكته قابل توجه در اين شكل تفاوت قطعيت شركت كنندكان در مورد تصميم اول و دوم است. براى بررسى تفاوت معنادارى ميزان قطعيت تصميم اول نسبت قدرت محرك تصميم اول با ميزان قطعيت تصميم دوم نسبت به قدرت محرك تصميم دوم از آزمون ويلكاكسون با ارزش

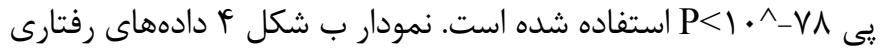
حاصل از گزارش قطعيت تصميم دوم نسبت به قطعيت تصميم اول را نشان مىدهد. اين ارتباط صعودى بوده و هر جه قطعيت تصميم اول بيشتر باشد، قطعيت تصميم دوم نيز بيشتر خواهد بود. ارزش يى حاصل

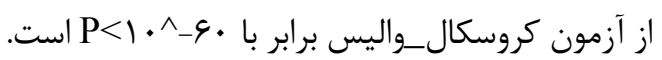

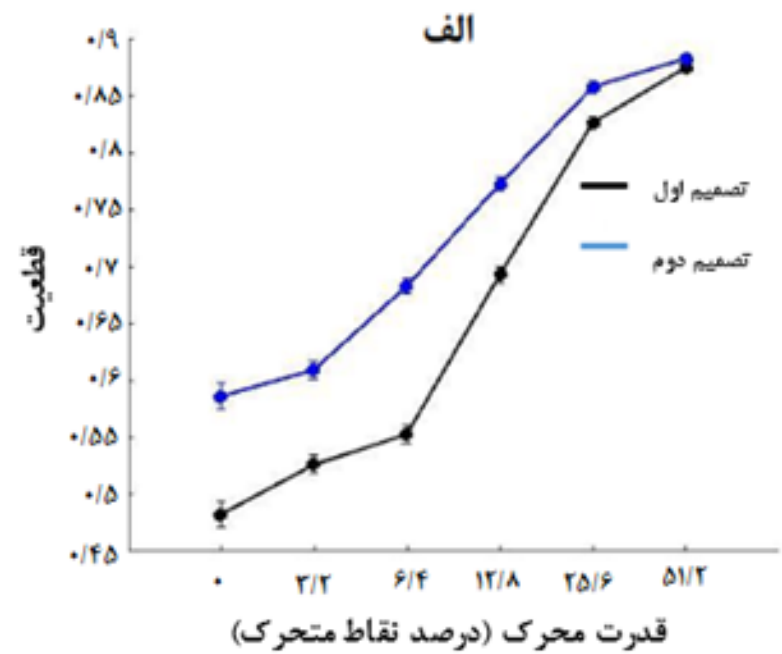

تصميم اول بررسى كنيم، همين روند صعودى مشاهده مىشود. براى بررسى معنادارى اين تغييرات، از آزمون معنادارى كروسكالـواليس با

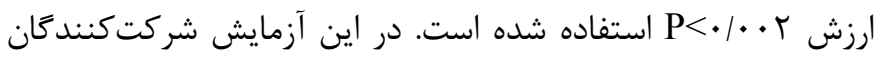
ميزان قطعيت خود را بر روى يك ميله رنغى صورت ييوسته گزارش مى كردند. براى بررسى تاثير ساير مولفهها بر ميزان قطعيت مىتوان

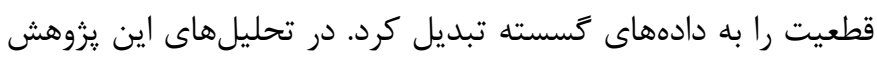
دادههاى ييوسته در اثر تبديل متغير قطعيت به له گروه گسسته الخيلى كم"، 》كم"، "ميانه"، "زياد" و "خيلى زياد" تبديل شدهاند. در شكل f قسمت الف ميزان تغييرات قطعيت تصميم اول و دوم نسبت به قدرت محرك هر تصميم نشان داده شده است. در اين شكل رنت مشكى نشاندهنده ميزان قطعيت تصميم اول و رنت آبى نشاندهنده ميزان قطعيت تصميم دوم است. نمودار بازگو مى كند كه با افزايش ميزان

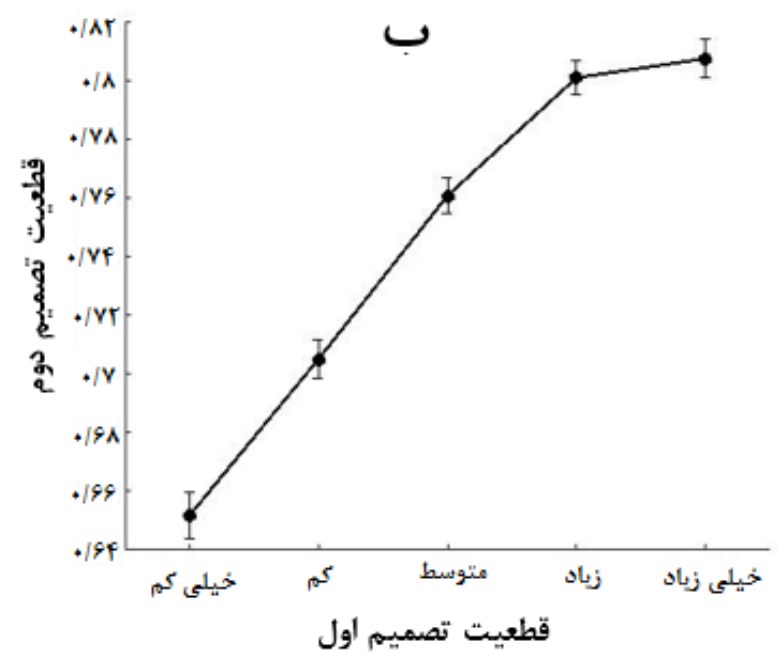

شكل F. الف) رابطه ميزان قطعيت با قدرت محرك. رنح مشكى براى تصميم اول و رنح آبى براى تصميم دوم. ب) رابطه قطعيت تصميم دوم نسبت به قطعيت تصميم اول

نيز همان نقش قطعيت ضمنى را ايفا مى كند. شركت كنندگان براى دريافت پاداش در هر آزمايه استراتثى بهينهاى را اتخاذ مى كنئد. شركت كنند زيرا تنها در صورت ياسخ صحيح به تصميم اول، ياسخ تصميم دوم اهميت ييدا مىكند. اين تفاوت زمانى، در قدرتهاى محرك كمتر، بيشتر است زيرا اين تصميمات سختتر به حساب مى آيند. بنابراين شركت كنندكان تلاش مى كنند تا با صرف زمان بيشترى در تصميم اول دقت خود و در واقع احتمال دريافت پاداش را افزايش دهند (شكل r). از طرفى شركت كنند نمى كردند بلكه بازخورد مثبت تنها در صورت درستى هر دو تصميم داده مىشد. شر كت كنند كان هنگامى كه تصميم اول را به درستى پِاسخ
در فرضيه يزوهش مطرح شد كه قطعيت آكَاهانه به عنوان تعيين كننده استراتزى در تصميمهاى دو مرحلهاى ادراكى نقش ايفا مىكند. در يزوهش Van den Berg و همكاران، قطعيت در هر مرحله توسط مرحاي شركت كنند

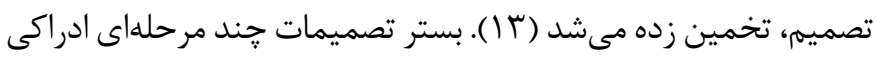
براى اين يروهش از آن جهت انتخاب شد كه اگر نتايج حاصل در اين

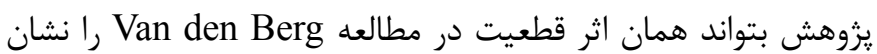
دهد، اثباتى براى نقش يكسان قطعيت آكاهانه و قطعيت ضمنى است. نتايج يزوهش حاضر نشان مىدهد كه قطعيت حتى در حالتى كه شركتكنندكان به صورت آكاهانه قطعيت خود را گزارش مى خدهند 
درسى به دانش آموزان است. براى مثال اگر سوالات به ترتيب آسان

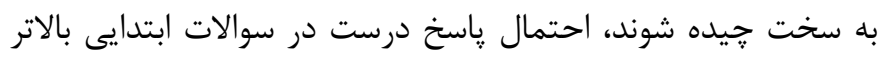

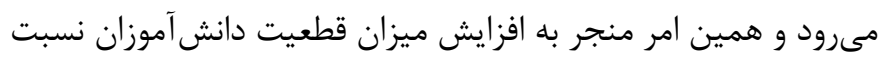

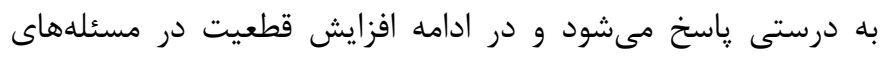

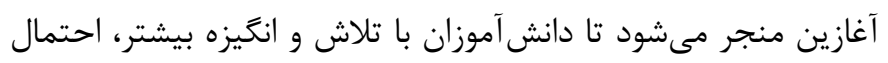

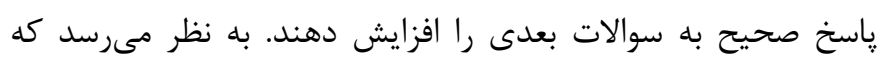

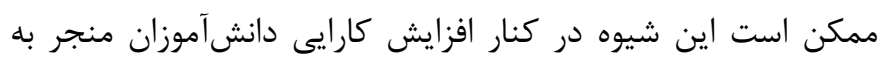

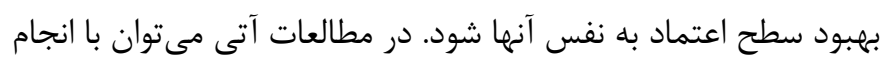

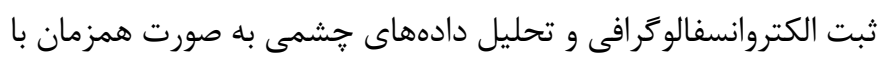

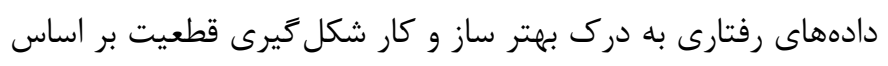
دادههاى جشمى و مغزى دست يُ بيدا كرد.

\section{نتيجه كيرى}

بررسى اثر قطعيت در تصميمهاى دو مرحلهاى ادراكى، هنگامى كه

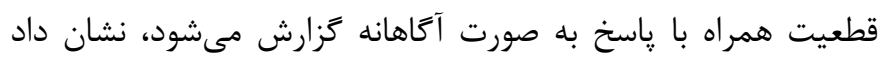

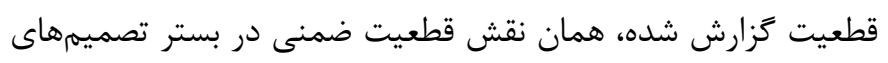

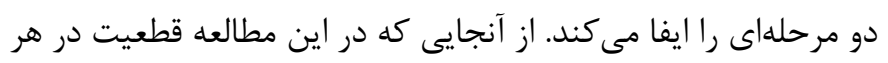

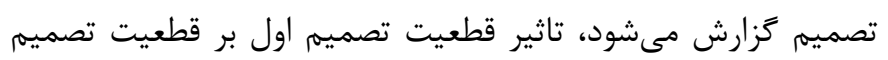

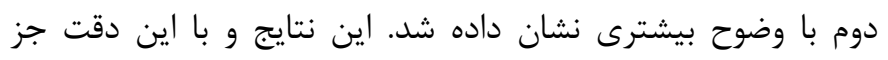
با كزارش صريح قطعيت توسط شركت كنندكان قابل مشاهده نبود.

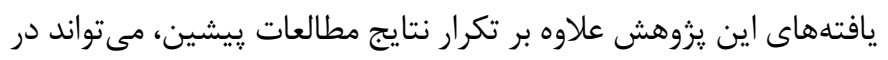

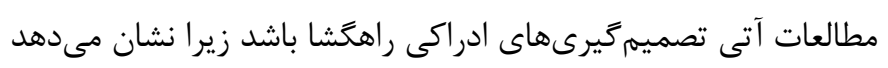
كه قطعيت كزارش شده همان نقش قطعيت ضمنى را دارد.

\section{تشكر و قدردانى}

اين يزوهش از يايانامه مورد حمايت ستاد علوم شناختى با شماره

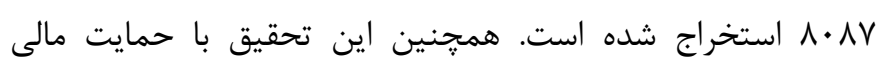

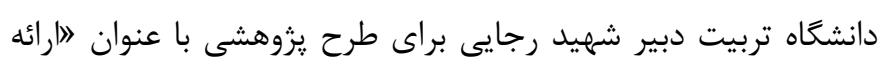

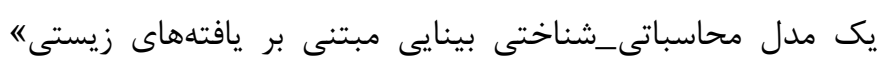
انجام كرفته است.

\section{References}

1. Sternberg RJ, Sternberg K. Cognitive psychology. 6th ed. Belmont:Wadsworth, Cengage Learning;2016.

2. Rezaian S, Kharrazi SK, Jamali E, Naderi A. A conceptual model of cognitive decision making. Advances in Cognitive
مى دادند نسبت به حالتى كه تصميم اول را اشتباه اتخاذ كرده بودند

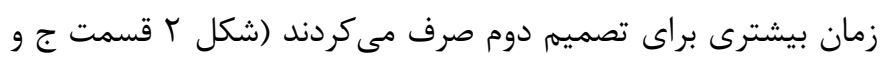

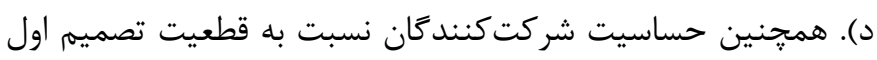
بيشتر بوده زيرا هنكامى كه تصميم اول را با قطعيت بالاترى اتخاذ مى كردند نسبت به شرايطى كه تصميم اول را با قطعيت يايين اتخاذ

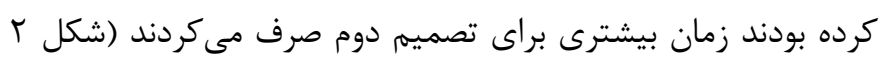

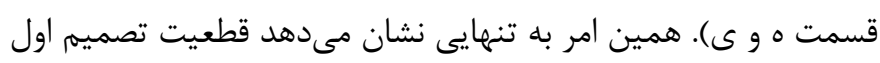

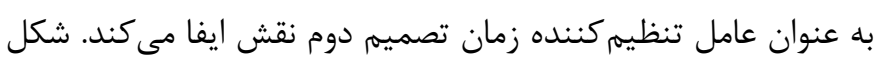

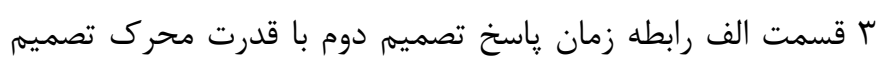

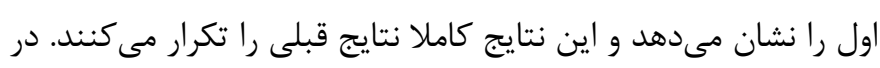

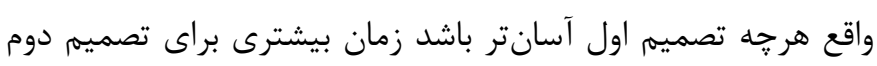

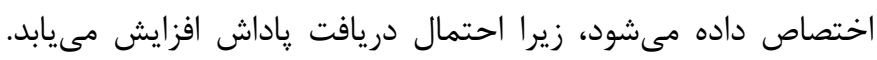

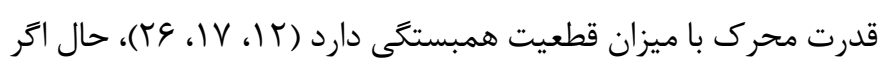

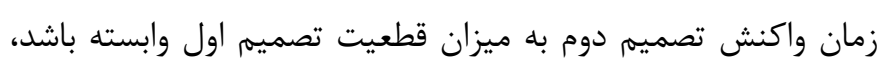

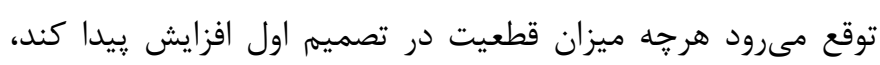

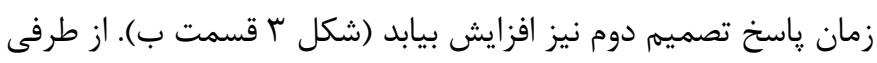

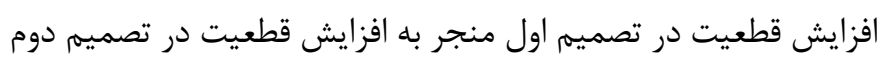

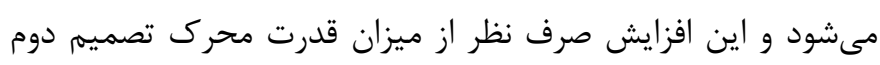

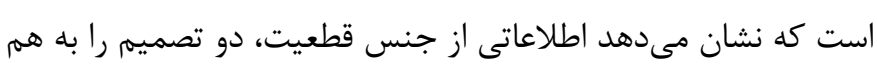

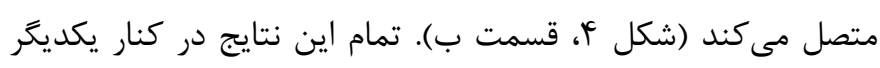
بيان مىكند قطعيت، در زمانى كه در هر مرحله به صورت آند آثاهانه

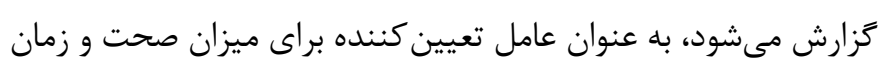

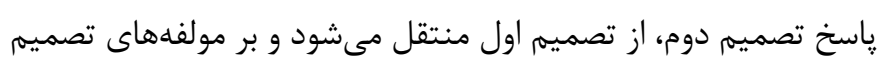

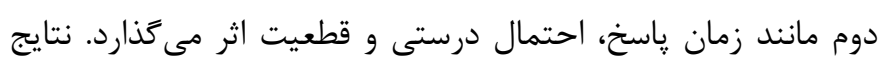

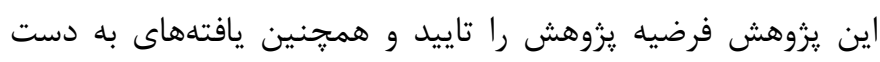

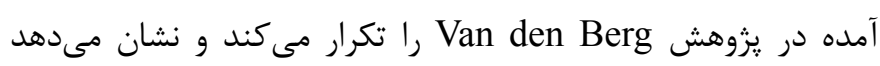

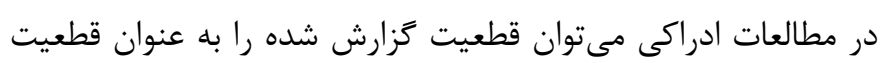
ضمنى شركت كنند أنان در نظر كرفت

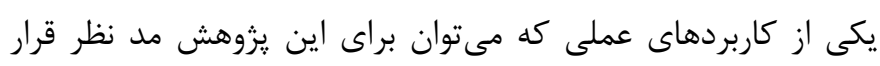

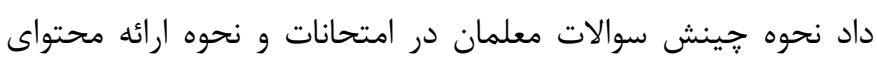

Sciences. 2019;21(1):1-20. (Persian)

3. Tversky A, Kahneman D. Judgment under uncertainty: Heuristics and biases. Science. 1974;185(4157):1124-1131.

4. Castanon SH, Moran R, Ding J, Egner T, Bang D, Sum- 
merfield C. Human noise blindness drives suboptimal cognitive inference. Nature Communications. 2019;10(1):1719.

5. Kording KP, Wolpert DM. Bayesian decision theory in sensorimotor control. Trends in Cognitive Sciences. 2006;10(7):319326.

6. Gold JI, Shadlen MN. The neural basis of decision making. Annual Review of Neuroscience. 2007;30:535-574.

7. Shadlen MN, Newsome WT. Neural basis of a perceptual decision in the parietal cortex (area LIP) of the rhesus monkey. Journal of Neurophysiology. 2001;86(4):1916-1936.

8. Hanks TD, Summerfield C. Perceptual decision making in rodents, monkeys, and humans. Neuron. 2017;93(1):15-31.

9. Bogacz R, Brown E, Moehlis J, Holmes P, Cohen JD. The physics of optimal decision making: a formal analysis of models of performance in two-alternative forced-choice tasks. Psychological Review. 2006;113(4):700-765.

10. Fechner GT, Howes DH, Boring EG. Elements of psychophysics. New York:Holt, Rinehart and Winston;1966.

11. Hirsh IJ, Watson CS. Auditory psychophysics and perception. Annual Review of Psychology. 1996;47(1):461-484.

12. Kiani R, Shadlen MN. Representation of confidence associated with a decision by neurons in the parietal cortex. Science. 2009;324(5928):759-764.

13. Van den Berg R, Zylberberg A, Kiani R, Shadlen MN, Wolpert DM. Confidence is the bridge between multi-stage decisions. Current Biology. 2016;26(23):3157-3168.

14. Luttrell A, Brinol P, Petty RE, Cunningham W, Díaz D. Metacognitive confidence: A neuroscience approach. Revista de Psicología Social. 2013;28(3):317-332.

15. Cheesman J, Merikle PM. Distinguishing conscious from unconscious perceptual processes. Canadian Journal of Psychology/Revue Canadienne De Psychologie. 1986;40(4):343367.

16. Mosavi Mezerji H, Sadeghi Marascht A, Sadeghi Abdollahi B, Khorrami Banaraki A. Study of difference of confidence in decision making in men and women. Advances in Cognitive Sciences. 2012;14(3):15-24. (Persian)

17. Kiani R, Corthell L, Shadlen MN. Choice certainty is informed by both evidence and decision time. Neuron. 2014;84(6):1329-1342.

18. Newsome WT, Britten KH, Movshon JA. Neuronal correlates of a perceptual decision. Nature. 1989;341(6237):52-54. 19. Britten KH, Shadlen MN, Newsome WT, Movshon JA. The analysis of visual motion: A comparison of neuronal and psychophysical performance. Journal of Neuroscience. 1992;12(12):4745-4765.

20. Shooshtari SV, Sadrabadi JE, Azizi Z, Ebrahimpour R. Confidence representation of perceptual decision by eeg and eye data in a random dot motion task. Neuroscience. 2019;406:510-527.

21. Olianezhad F, Zabbah S, Ebrahimpour R. The influence of past decision information on decision making in the present. Shefaye Khatam. 2016;4(3):1-8. (Persian)

22. Heekeren HR, Marrett S, Bandettini PA, Ungerleider LG. A general mechanism for perceptual decision-making in the human brain. Nature. 2004;431(7010):859-862.

23. Hanks T, Kiani R, Shadlen MN. A neural mechanism of speed-accuracy tradeoff in macaque area LIP. Elife. 2014;3:e02260.

24. Roitman JD, Shadlen MN. Response of neurons in the lateral intraparietal area during a combined visual discrimination reaction time task. Journal of Neuroscience. 2002;22(21):94759489 .

25. Palmer J, Huk AC, Shadlen MN. The effect of stimulus strength on the speed and accuracy of a perceptual decision. Journal of Vision. 2005;5(5):376-404.

26. Boldt A, Schiffer A-M, Waszak F, Yeung N. Confidence predictions affect performance confidence and neural preparation in perceptual decision making. Scientific Reports. 2019;9(1):4031. 